\title{
POSTCOLONOSCOPY ACUTE APPENDICITIS - OUR CASE SERIES AND A REVIEW OF LITERATURE
}

\author{
Bogdan SOCEA ${ }^{1 凶}$, Alexandru C. SMARANDA ${ }^{1}$, Anca A. NICA ${ }^{1}$, Ovidiu G. BRATU ${ }^{2}$, \\ Camelia C. DIACONU ${ }^{3}$, Vlad D. BĂLEANU ${ }^{1}$, Dragoș V. DAVIȚOIU ${ }^{1}$, Mihai DIMITRIU ${ }^{4}$, \\ Alexandru C. CARÂP ${ }^{1}$, Simona BOBIC ${ }^{1}$, Vlad D. CONSTANTIN ${ }^{1}$
}

${ }^{1}$ Emergency Clinical Hospital „Sfântul Pantelimon“, General Surgery Clinic, „Carol Davila“ University of Medicine and Pharmacy, Bucharest, Romania

2 Emergency Universitary Central Military Hospital, Department of Urology, „Carol Davila“ University of Medicine and Pharmacy, Academy of Romanian Scientists, Bucharest, Romania

${ }^{3}$ Clinical Emergency Hospital of Bucharest, Internal Medicine Clinic, „Carol Davila“ University of Medicine and Pharmacy, Bucharest, Romania

${ }^{4}$ Emergency Clinical Hospital „Sfântul Pantelimon“, Obstetrics and Gynecology Clinic, „Carol Davila“ University of Medicine and Pharmacy, Bucharest, Romania

Received 17 Sept 2018, Accepted 09 Nov 2018

https://doi.org/10.31688/ABMU.2018.53.4.19

\begin{abstract}
Colonoscopy is a common diagnostic procedure for colon. Colonic perforation is a well-known iatrogenic complication of diagnostic colonoscopy. However, appendiceal involvement with inflammation or perforation is extremely rare and only a few cases of post-colonoscopy appendicitis have been reported so far. We describe a series of four cases operated in our clinic for acute appendicitis that developed in young age, shortly after colonoscopic examination for another pathology (irritable bowel syndrome, diverticular colonic disease, left iliac fossa and left flank pain).
\end{abstract}

Keywords: colonoscopy, acute appendicitis, post-colonoscopy appendicitis.

\begin{abstract}
Résumé
Appendicite aigue après coloscopie- série des cas et revue de la littérature

La coloscopie est une procédure de diagnostic courante pour le côlon. La perforation du côlon est une complication iatrogène bien connue de la coloscopie diagnostique. Toutefois, les atteintes appendiculaires avec inflammation ou perforation sont extrêmement rares et seuls quelques cas d'appendicite aiguë après coloscopie ont été rapportés jusqu'à présent. Nous décrivons une série de quatre cas opérés dans notre clinique d'appendicite aiguë, qui se sont développés à un jeune âge, peu après la coloscopie d'une autre pathologie (syndrome de l'intestin irritable, maladie diverticulaire du côlon, douleur a la fosse iliaque gauche et au flanc gauche).
\end{abstract}

Mots-clés: coloscopie, appendicite aiguë, appendicite après coloscopie. 


\section{INTRODUCTION}

Acute appendicitis has been sporadically reported in literature as a possible complication after colonoscopy (until 2007 only 12 cases were reported) ${ }^{1}$. Acute appendicitis following colonoscopic examination is a rare complication, with a considered incidence of $0.038 \%$, according to another research performed in 2007, either because of under-publication or under-recognition due to simultaneous conservative treatment ${ }^{2}$.

A study published in 2013 identified 27 previously reported cases of post-colonoscopy appendicitis in the peer-reviewed literature ${ }^{3}$.

\section{Cases presentation}

In a retrospective study period of 20 years (between 1998-2017), performed in the General Surgery Clinic of the Emergency Clinical Hospital „Sfântul Pantelimon", Bucharest, Romania, we identified four cases of acute appendicitis which could be related to a previously colonoscopic examination. The colonoscopy was performed, in our cases, between 12 and 48 hours before the clinical onset of acute appendicitis. In three cases, the procedure was performed in our center, and in one case in the ambulatory.

The physical signs were: lower right abdominal pain gradually intensified, accompanied by nausea, vomiting, fever, diffusely tender abdomen, especially in the lower right quadrant, with rebound tenderness and guarding.

No one of the patients had symptoms that could suggest acute appendicitis at the colonoscopy time or previously, so we could exclude an exacerbation of a preexisting condition.

On the other hand, it seems possible that the development of appendicitis after colonoscopy could be a coincidence and that could not be totally excluded scientifically. But the most probable supposition is that of chronological succession and of causal link to colonoscopy. Impaction of stool by barotraumas, or direct appendicular trauma could be the etiological mechanism.

From the four cases, there was a woman, 26 years of age, and three men with ages: 37,42 and respectively 45 years of age. The ages of our patients are lower compared to medium ages reported in literature.

The colonoscopy was performed, in all cases, for left flank and left iliac fossa pain. Colonoscopy findings were two cases of sigmoid diverticular disease, one associated to sigmoid endometriosis (the patient of female gender), confirmed by histopathological exam - the only biopsy performed in our series.

For the other two cases (two men), the established diagnosis was irritable bowel syndrome, since no other pathologic condition was found to explain the symptomatology (so the diagnostic was an exclusion one). No significant abnormalities were found through the colonoscopy and no biopsy was performed for these two patients.

There were no signs of inflammation in the caecum or around the appendiceal orifice for all colonoscopies.

The diagnosis was suspected by clinical findings, suggested by high white blood count in all cases and confirmed by computed tomography scan in three cases (that also excluded a post-colonoscopy perforation).

All the cases were operated in our clinic, three open and one laparoscopically (the patient of female gender). Intraoperatively, we found one case of gangrenous appendicitis (a patient of male gender), that required also a drain, and three cases of phlegmonous appendicitis that underwent simple appendectomy, subsequently confirmed by histopathological examination. Macroscopically, we found a coprolith in two cases, that confirmed the impaction theory.

Postoperative outcome was very good in all cases, with discharge in 48 hours after procedure.

\section{Discussion}

The two known causes of iatrogenic appendicitis are barium-contrast examination and colonoscopy. Impaction of barium in lumen could be the trigger of inflammation ${ }^{4}$.

The theories of post-colonoscopy appendicitis include fecalith impaction into the appendiceal lumen and/or direct appendiceal trauma by gas insufflation or direct instrumentation and appendiceal trauma during procedure ${ }^{5,6}$. Appendiceal trauma lead to lumen obstruction by intralumenal bleeding or edema (Figure 1).

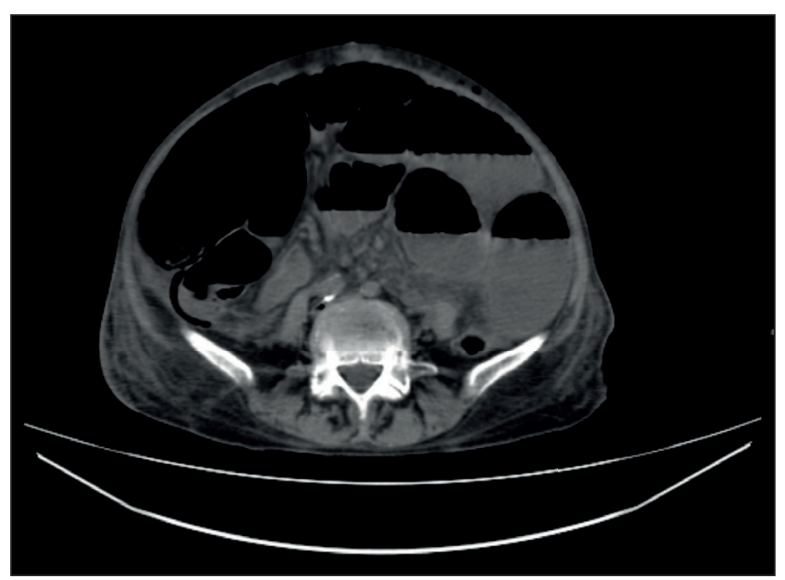

Figure 1. Computed tomography scan. Hyper-inflated appendix and hydroaeric images in a case of acute gangrenous appendicitis post-colonoscopy. 
Another theory includes exposure of the mucosa to the residual glutaraldehyde-type solution used in cleaning the endoscope, leading to inflammation ${ }^{6}$.

In 1988, Houghton and Aston first reported appendicitis as a rare complication of colonoscopy ${ }^{5}$.

Another particular type of iatrogenic appendiceal inflammation is stump appendicitis, due to an incomplete previously appendiceal resection (in most cases post laparoscopic resection)?

Diverticular colonic disease could be, on the one hand, the reason of colonoscopic examination, and, on the other hand, it could represent an important point in differential diagnosis. A caecum diverticulitis could mimic an acute appendicitis ${ }^{8}$ and appendiceal diverticulosis could be at the origin of this organ inflammation?.

There are several cases reported in the literature that associate inflammatory bowel disease, such as ulcerative colitis ${ }^{10}$. There are also many other causes that may cause adjacent inflammatory processes (eg. cardiac pathologies, various pathogen infections, patient medication, etc. $)^{11-18}$.

One case presented with high level of total bilirubin, which could be a marker of severe appendicitis $^{19}$, and one case (the 26-year-old woman) also confirmed an endometriosis tissue isle developed on sigmoid diverticular disease ${ }^{20}$.

\section{Conclusions}

In our opinion, acute post-colonoscopy appendicitis may be an incidental finding or a direct consequence of the procedure. The mechanism of developing appendiceal inflammation is rather unknown, than theoretical assumptions. However, acute appendicitis should be considered in the differential diagnosis of a post-colonoscopy abdominal pain, in order to avoid a delayed diagnosis and complications such as perforation of the appendix ${ }^{21,22}$ and peritonitis. The clinical awareness of post-colonoscopy appendicitis must be increased.

The best diagnostic method is computed tomography, which has high sensitivity and specificity to detect acute appendicitis ${ }^{23}$ and is more accurate than ultrasonography $y^{24}$.

\section{Compliance with Ethics Requirements:}

"The authors declare no conflict of interest regarding this article"

„The authors declare that all the procedures and experiments of this study respect the ethical standards in the Helsinki Declaration of 1975, as revised in 2008(5), as well as the national law. Informed consent was obtained from all the patients included in the study"

"No funding for this study"

\section{References}

1. Pellish R, Ryder B, Habr F. An unusual complication: post-colonoscopy appendicitis. Endoscopy 2007; 39 (1, article E138).

2. Chae HS, Jeon SY, Nam WS, et al. Acute appendicitis caused by colonoscopy. Korean Journal of Internal Medicine 2007; 22(4):308-311.

3. April MD, Simmons JR, Nielson AS. An unusual cause of post-colonoscopy abdominal pain. Am J Emerg Med 2013;3 1(1):273.e1-4.

4. Sisley JF, Wagner CW. Barium appendicitis. South Med J 1982;75:498-499.

5. Houghton A, Aston N. Appendicitis complicating colonoscopy. Gastrointest Endosc 1988; 34: 489.

6. Vender R, Larson J, Garcia J, Topazian M, Ephraim P. Appendicitis as a complication of colonoscopy. Gastrointest Endosc 1995; 41: 514-516.

7. Constantin V, Popa F, Carâp A, Socea B. Stump appendicitis - an overlooked clinical entity. Chirurgia (Bucur) 2014; 109(1):128-31.

8. Socea B, Nica A, Smaranda C, Carâp A, et al. Solitary cecum diverticulitis - A surprising diagnosis. Arch Balk Med Union 2017; 52(4): 467-470.

9. Constantin VD, Carâp A, Nica A, Smaranda A, Socea B. Appendiceal diverticulitis - a case report. Chirurgia (Bucur) 2017; 112(1):82-85.

10. Bachir NM, Feagins LA. Post-colonoscopy appendicitis in a patient with active ulcerative colitis. World J Gastrointest Endosc 2010; 2(6):232-4.

11. Bungau S, Bungau C, Tit DM, Pallag A. The influence of specialized academic studies on self-medication. Rev Rom Bioet 2015; 13(1):153-158.

12. Diaconescu D, Pantea Stoian A, Socea LI, et al. Hepatorenal syndrome: a review. Arch Balk Med Union 2018; 53(2): 239-245.

13. Diaconu CC, Dragoi CM, Bratu OG, et al. New approaches and perspectives for the pharmacological treatment of arterial hypertension. Farmacia 2018; 66(3):408-415.

14. Diaconu CC, Manea M, Iancu MA, et al. Hyponatremia in patients with heart failure: a prognostic marker. Rev Chim (Bucharest) 2018; 69(5):1071-1074.

15. Diaconu CC, Stănescu AMA, Pantea Stoian A, et al. Hyperkalemia and cardiovascular diseases: new molecules for the treatment. Rev Chim (Bucharest) 2018; 69(6):1367-1370.

16. Bumbu A, Pasca B, Tit DM, Bungau S, Bumbu G. The effects of soy isoflavones and hormonal replacing therapy on the incidence and evolution of postmenopausal female urinary incontinence. Farmacia 2016; 64(3):419-422.

17. Stanimir M, Chiutu LC, Wese S, Milulescu A, Nemes RN, Bratu O. Mullerianosis of the urinary bladder: a rare case report and review of the literature. Rom J Morphol Embriol 2016; 57(Suppl 2): 849-852.

18. Stoicescu M, Csepento C, Mutiu G, Bungau S. The role of increased level of plasma renin in etiopathogenic arterial hypertension in the young. Rom J Morphol Embriol 2011; 52(1 Suppl.):419-423.

19. Socea B, Carâp A, Rac-Albu M, Constantin V. The value of serum bilirubin level and of white blood cell count as severity markers for acute appendicitis. Chirurgia (Bucur) 2013;108(6):829-34.

20. Constantin V, Carâp A, Bobic S, et al. Accurate diagnosis of sigmoid colon endometriosis by immunohistochemistry and 
transmission electron microscopy - a case report. Chirurgia (Bucur) 2015;110(5):482-5.

21. Paramythiotis D, Kofina K, Papadopoulos V, Michalopoulos A. Diagnostic colonoscopy leading to perforated appendicitis: a case report and systematic literature review. Case Rep Gastrointest Med 2016;2016:1378046.

22. Zhou XC, Huang CW, Dai YY, Huang ZY, Lou Z. Perforated appendicitis after colonoscopy: cause or coincidence? A rare case report and literature review. Medicine (Baltimore) 2017;96(46):e8747.

23. Pickhardt PJ, Lawrence EM, Pooler BD, et al. Diagnostic performance of multidetector computed tomography for suspected acute appendicitis. Ann Intern Med 2011;154:789-96.

24. Terasawa T, Blackmore CC, Bent S, et al. Systematic review: computed tomography and ultrasonography to detect acute appendicitis in adults and adolescents. Ann Intern Med 2004;141:537-46. 